\title{
Meningkatkan Kemampuan dalam Mengoperasionalkan Penjumlahan dan Pengurangan Menggunakan Metode Demontrasi Siswa Kelas II SDN No. 101/II Muara Bungo Kec. Pasar Muara Bungo Kabupaten Bungo
}

\author{
Rosmiati \\ SD Negeri No. 101/II Muara Bungo, Kabupaten Bungo Propinsi Jambi \\ rosmiati@yahoo.com
}

\begin{abstract}
Abstrak
Tujuan penelitian ini adalah untuk mengetahui apakah penggunaan metode demonstrasi dapat meningkatkan kemampuan mengoperasionalkan penjumlahan dan pengurangan pada siswa kelas II SDN No. 101/II Muara Bungo Kecamatan Pasar Muara Bungo Kabupaten Bungo. Penelitian tindakan kelas dilaksanakan dalam dua siklus dan setiap siklus melalui empat tahap yaitu merencanakan, melakukan tindakan, mengamati dan melakukan refleksi. Pada siklus I rata-rata hasil kemampuan siswa dalam mengoperasionalkan penjumlahan dan pengurangan menggunakan metode demonstrasi tergolong kurang dengan nilai rata-rata hasil tes 47,67 dan persentase nilai sebesar 48\%. Pada siklus II, nilai rata-rata hasil tes sebesar 7,5 dan persentase nilai sebesar 75\%. Berdasarkan hasil penelitian, maka pembelajaran operasi penjumlahan dan pengurangan menggunakan metode demonstrasi dapat meningkatkan kemampuan siswa.
\end{abstract}

Kata Kunci: Operasi penjumlahan, pengurangan, metode demondtrasi.

\begin{abstract}
The purpose of this study is to determine whether the use of demonstration methods can improve the ability to operationalize the addition and subtraction of classroom students II SDN No. 101/II Muara Bungo Kecamatan Pasar Muara Bungo Kabupaten Bungo. Classroom action research is carried out in two cycles and each cycle through four stages of planning, action, observation and reflection. In the first cycle, the result of the students' ability in operationalizing the sum and subtraction using the demonstration method is less than the average score of 47.67 test result and the percentage value of $48 \%$. In cycle II, the average score of the test result is 7.5 and the percentage value is $75 \%$. Based on the results of the research, the learning of addition and reduction operations using demonstration methods can improve students' ability.
\end{abstract}

Keywords: Addition Operation, Subtraction, Demonstration Method 


\section{PENDAHULUAN}

Kegiatan proses belajar mengajar merupakan suatu kegiatan yang berkesinambungan yang tujuan utamanya yaitu siswa dapat menyerap materi pelajaran dan memahami konsep materi pembelajaran. Russeffendi (1991:138) menggemukakan bahwa konsep dalam matematika adalah ide atau gagasan yang memungkinkan kita untuk mengelompokan tanda (objek) dipelajari definisi atau pengamatan langsung seperti melihat, mendengar, mendiskusikan, dan memikirkan tentang kebenaran contoh. kedalam contoh. Atau dapat diartikan bahwa konsep matematika abstrak yang memungkinkan kita untuk mengelompokkan (mengklasifikasikan) objek atau kejadian. Pemahaman matematika perlu ditanamkan kepada peserta didik sejak dini. Sejak anak masih duduk di bangku sekolah dasar pemahaman konsep sangat diperlukan (Suherman;2006). Di sana mereka dituntut mengerti tentang definisi, pengertian, cara pemecahan masalah maupun pengoperasian matematika secara benar, karena akan menjadi bekal dalam mempelajari matematika pada jenjang pendidikan yang lebih tinggi.

Hasil analisis ulangan harian pada materi operasi penjumlahan dan pengurangan tahun pelajaran 2013/2014 di SDN No. 101/II Muara Bungo Kecamatan Pasar Muara Bungo Kabupaten Bungo Kelas II pada mata pelajaran Matematika secara klasikal hanya 47\% siswa mencapai nilai 7,0 ke atas dan rata-rata nilai prestasi siswa hanya mencapai nilai 6,19. Dari hasil ulangan harian tersebut, hanya 14 orang dari 30 siswa kelas II SDN No. 101/II Muara Bungo Kecamatan Pasar Muara Bungo Kabupaten Bungo yang mencapai tingkat penguasaan materi sebesar $78 \%$ ke atas pada mata pelajaran Matematika materi operasi penjumlahan dan pengurangan.

Selama pembelajaran berlangsung, siswa pada umumnya bersifat pasif, jarang sekali siswa mengajukan pertanyaan atau memberi tanggapan terhadap penjelasan guru. Berdasarkan hal tersebut, penulis melakukan identifikasi permasalahan dalam pembelajaran antara lain: (a) penguasaan anak terhadap materi pembelajaran operasi pengurangan rendah, (b) tidak semua anak dapat menjawab pertanyaan yang diajukan 
guru dengan baik dan benar tentang operasi pengurangan, (c) anak kurang mampu untuk melaksanakan tugas yang diberikan guru, (d) anak kurang dilibatkan dalam proses pembelajaran karena metode yang terlalu terpaku pada guru, (e) terdapat pemahaman yang kurang merata diantara semua siswa tentang materi pembelajaran operasi penjumlahan dan pengurangan.

Hasil obervasi peneliti di SDN No. 101/II Muara Bungo Kecamatan Pasar Muara Bungo Kabupaten Bungo, diketahui bahwa faktor penyebab siswa kurang memahami materi yang diajarkan adalah tidak ada motivasi dan kurangnya perhatian siswa dalam pembelajaran, siswa kurang terlibat dalam proses pembelajaran yang diadakan oleh guru, dalam pembelajaran matematika para guru dituntut untuk menggunakan model pembelajaran yang dapat meningkatkan motivasi siswa dalam belajar (Muhsetyo;2005). Pemerataan pemahaman materi pembelajaran dapat meningkatkan ketuntasan belajar siswa secara klasikal mencapai minimal $85 \%$. Penggunaan metode demonstrasi merupakan salah satu upaya dalam mengatasi kesulitan dalam pemahaman konsep operasi penjumlahan dan pengurangan. Metode demonstrasi dapat membantu siswa dalam memahami konsep operasi penjumlahan dan pengurangan. Dengan demikian penggunaan metode tersebut diharapkan dapat meningkatkan kemampuan pemahaman konsep operasi penjumlahan dan pengurangan, sehingga pemahaman matematika akan meningkat.

\section{METODE PENELITIAN}

Penelitian tindakan kelas dilaksanakan melalui proses pengkajian berdaur yang terdiri dari empat tahap yaitu merencanakan, melakukan tindakan, mengamati dan melakukan refleksi (Arikunto:2010). Penelitian tindakan kelas dilakukan dalam dua siklus, setiap siklus diawali dengan perencanaan penerapan tindakan dan observasi, serta diakhiri dengan refleksi. Subjek penelitian ini adalah siswa kelas II SDN No. 101/II Muara Bungo Kecamatan Pasar Muara Bungo Kabupaten Bungo yang berjumlah 30 orang siswa. 
Penelitiaan ini dilaksanakan mulai 01 Februari 2014 sampai 29 Februari 2014 pada semester II tahun pelajaran 2013/2014. Jenis data yang digunakan dalam penelitian ini adalah data primer yang berkaitan dengan nilai tes kemampuan mengoperasionalkan penjumlahan dan pengurangan. Sumber data sekunder diperoleh dari respon siswa. Data dikumpulkan menggunakan lembaran pengamatan atau pedoman observasi selama kegiatan pembelajaran dan lembar soal tes operasi penjumlahan dan pengurangan.

Analisis data dilakukan dengan membandingkan hasil pada siklus pertama dengan siklus-siklus selanjutnya. Hasil pengamatan setiap siklus dianalisis secara kualitatif dan kuantitatif. Analisis deskritptif kualitatif digunakan untuk memaparkan pelaksanaan kegiatan PTK dengan menggambarkan hasil observasi yang dilakukan oleh kolaborator selama pembelajaran berlangsung. Analisis deskriptif digunakan untuk menggambarkan sebaran data hasil PTK dengan menggunakan teknik prosentase dan rata-rata terhadap hasil evaluasi yang dilakukan pada saat proses pembelajaran berlangsung dan pada akhir materi pembelajaran.

Siswa dikatakan tuntas belajar secara individu jika siswa telah menguasai sebesar $70 \%$ dari materi yang diujikan. Perhitungan persentase penguasan materi berdasarkan tes menulis permulaan yaitu sebagai berikut:

\section{Keterangan:}

$$
K T=\frac{n}{N} x 100 \%
$$

KT $=$ Persentase ketuntasan belajar

$\mathrm{n} \quad=$ Jumlah skor yang didapatkan siswa

$\mathrm{N} \quad$ = Skor maksimal. (Diknas, 2006: 14)

Kemudian hasil penilaian dikualifikasikan dengan berpedoman pada skala penilaian yang diambil dari pendapat Wardhani (2004:153-156) yaitu seperti yang digambarkan pada tabel berikut:

Tabel 1 Tabel Skala Penilaian

\begin{tabular}{cc}
\hline Interval Persentase Penguasaan & Keterangan \\
\hline $85 \%-100 \%$ & Baik Sekali \\
\hline
\end{tabular}




\begin{tabular}{cc}
\hline Interval Persentase Penguasaan & Keterangan \\
\hline $75 \%-84 \%$ & Baik \\
\hline $60 \%-74 \%$ & Cukup \\
\hline $40 \%-59 \%$ & Kurang \\
\hline $0 \%-39 \%$ & Gagal \\
\hline
\end{tabular}

Penelitian ini dikatakan berhasil jika mampu meningkatkan $85 \%$ siswa mencapai batas nilai kriteria ketuntasan minimal yang ditentukan di SDN No. 101/II Muara Bungo Kecamatan Pasar Muara Bungo Kabupaten Bungo.

\section{HASIL DAN PEMBAHASAN}

Siklus pertama dilakukan dalam 3 kali pertemuan, dimana setiap pertemuan dilakukan dalam waktu 2 jam pelajaran ( 2 x 35 menit). Pada pertemuan pertama, pembelajaran dilaksanakan dengan memperkenalkan materi operasi penjumlahan dan pengurangan terhadap siswa dan mengkaitkannya dengan peristiwa sehari-hari yang berkaitan dengan operasi penjumlahan dan pengurangan. Pada pertemuan kedua, siswa diajarkan untuk mengetahui simbol penjumlahan dan pengurangan dan siswa mampu menyelesaikan soal-soal penjumlahan dan pengurangan. Pada pertemuan ketiga, siswa diajak untuk menghafal fakta dasar penjumlahan dan pengurangan dan mampu melakukan penjumlahan dan pengurangan untuk konsep bilangan 3 angka. Pada siklus pertama ini, guru melaksanakan pembelajaran materi operasi penjumlahan dan pengurangan menggunakan metode demonstrasi dan media benda konkrit berupa lidi.

Secara keseluruhan pelaksanaan tindakan kelas pada siklus I digambarkan sebagai berikut: (1) Perencanaan, menyunsun rpp matematika materi operasi penjumlahan dan pengurangan, mengembangkan instrumen observasi guru dan siswa. Peneliti juga mempersiapkan media pembelajaran berupa spidol 2 buah, kertas plano, dan media berupa lidi sebagai alat untuk mendemonstrasikan operasi penjumlahan dan pengurangan. (2) Pelaksanaan Tindakan, guru melakukan apersepsi untuk memberikan motivasi dan mengarahkan siswa kemudian menjelaskan tujuan pembelajaran dan menjelaskan langkah-langkah pembelajaran. 
Pelaksanaan pembelajaran pada pertemuan pertama diawali dengan guru mencontohkan peristiwa-peristiwa yang berhubungan dengan operasi penjumlahan dan pengurangan yang bisa ditemui dalam kehidupan sehari-hari. Pada tahap selanjutnya guru menjelaskan konsep pembelajaran dengan metode demonstrasi dan media lidi.

Guru melakukan demonstrasi operasi penjumlahan dan pengurangan menggunakan gambar yang ditempelkan di papan tulis. Guru mendemonstrasikaan operasi penjumlahan dan pengurangan menggunakan lidi yang telah disiapkan. Guru meminta siswa ikut mendemonstrasikan penjumlahan dan pengurangan dengan media yang dibawa oleh masing-masing siswa dari rumah. Selain itu, siswa kemudian diminta untuk mengerjakan soal-soal latihan yang sudah disiapkan.

Kegiatan penutup dilakukan guru dengan menyimpulkan hasil kegiatan belajar mengajar yang sudah dilaksanakan dan meminta siswa untuk lebih aktif dalam belajar baik di rumah maupun di sekolah. Guru mengadakan evaluasi dengan menggunakan tes pilihan berganda yang terdiri dari 10 item pertanyaan mengenai operasi penjumlahan dan pengurangan.

Berdasarkan hasil observasi terhadap kegiatan guru dalam melaksanakan kegiatan pembelajaran matematika materi operasi penjumlahan dan pengurangan, semua hal yang ada dalam instrumen penilaian kegiatan guru dilakukan dengan cukup baik sesuai dengan urutan dalam rancangan pelaksanaan pembelajaran matematika materi operasi penjumlahan dan pengurangan. Tetapi pada beberapa indikator penilaian kegiatan guru masih ada yang perlu ditingkatkan antara lain penjelasan langkah-langkah pelaksanaan pembelajaran.

Berdasarkan hasil observasi terhadap siswa. Perhatian siswa terhadap demonstrasi yang dilakukan oleh guru tergolong cukup. Siswa bertanya tentang hal yang belum dimengerti tergolong baik, aktif dalam menjawab pertanyaan, mengerjakan soal-soal yang diberikan, menyelesaikan soal yang diberikan sesuai waktu yang ditentukan, memahami konsep operasi penjumlahan dan pengurangan, membantu menjelaskan hal yang belum dimengerti oleh yang lain, melakukan 
peragaan/demonstrasi operasi penjumlahan dan pengurangan dengan benda konkrit masih kurang. Keadaan ini dikarenakan bahwa masih banyak siswa yang masih belum mengerti dengan konsep materi pembelajaran.

Penilaian terhadap hasil tes hasil belajar pada siklus I, digambarkan pada Tabel 2.

Tabel 2 Distribusi Frekuensi Hasil Belajar Matematika Siswa pada Siklus I

\begin{tabular}{ccccc}
\hline No & Interval Persentase (\%) & Frekuensi & Kriteria & Persentase (\%) \\
\hline 1 & $85-100$ & 0 & Baik Sekali & 0,00 \\
\hline 2 & $75-84$ & 0 & Baik & 0,00 \\
\hline 3 & $60-74$ & 8 & Cukup & 26,67 \\
\hline 4 & $40-59$ & 18 & Kurang & 60,00 \\
\hline 5 & $0-39$ & 4 & Gagal & 13,33 \\
\hline & Jumlah & 30 & & 100,00 \\
\hline & Rata-rata Persentase & $47,67 \%$ & Kurang
\end{tabular}

Berdasarkan hasil penilaian terhadap hasil kemampuan belajar matematika siswa dalam materi operasi penjumlahan dan pengurangan dengan menggunakan instrumen tes yang terdiri dari 10 item pertanyaan pilihan berganda, digambarkan bahwa sebanyak 8 orang siswa atau 26,67\% dari jumlah keseluruhan siswa dengan kemampuan cukup pada operasi penjumlahan dan pengurangan, sedangkan 18 siswa atau $60,00 \%$ dengan kemampuan pengoperasionaloan pengurangan kurang, dan 4 siswa (13,33\%) dengan kemampuan mengoperasionalkan penjumlahan dan pengurangan gagal. Berdasarkan tabel di atas dapat dilihat bahwa rata-rata siswa memiliki hasil belajar matematika sebesar 47,67\% dan berkategori kurang.

Berdasarkan hasil pengamatan pada siklus pertama ini, maka ditemukan beberapa kekurangan yang perlu diperbaiki antara lain sebagai berikut: (1) antusiasme siswa dalam mengikuti kegiatan pembelajaran masih tergolong kurang, (2) siswa masih banyak yang belum memahami kegiatan pembelajaran operasi penjumlahan dan pengurangan yang dilaksanakan, (3) pada saat kegiatan pembelajaran dilaksanakan, siswa masih banyak yang kelihatan kebingungan dan tidak tahu apa yang harus dilakukan.

Dalam perencanaan tindakan kelas siklus II, peneliti telah menyusun rencana perbaikan pembelajaran dengan melakukan penyempurnaan sesuai dengan 
kekurangan yang terjadi berdasarkan hasil refleksi siklus I. Selain itu, sepertihalnya pada siklus sebelumnya, guru mengembangkan instrumen untuk pengamatan guru dan siswa pada saat kegiatan pembelajaran dan instrumen tes hasil belajar serta permasalahan yang harus dibahas dalam pembelajaran. Guru juga mengembangkan skenario pembelajaran dengan memasukkan unsur-unsur permainan dalam materi pembelajaran dengan menggunakan media kerikil untuk memancing minat dan perhatian siswa. Peneliti juga mempersiapkan media pembelajaran berupa spidol 6 buah dan media gambar dan media benda konkrit berupa kerikil.

Pada pelaksanaan tindakan siklus II, dimulai dengan guru melakukan apersepsi dan motivasi terhadap siswa dan mengarahkan siswa pada pembelajaran yang akan dilaksanakan, menjelaskan tujuan yang akan dicapai dalam pembelajaran dan menjelaskan langkah-langkah pelaksanaan pembelajaran. Pada tahap awal pelaksanaan tindakan, guru melakukan eksplorasi terhadap berbagai kegiatan yang dilakukan oleh siswa dalam kehidupan sehari-hari yang berhubungan dengan operasi penjumlahan dan pengurangan. Untuk memancing siswa terlibat dalam kegiatan pembelajaran, guru memasukkan unsur permainan yang berupa tebak-tebakan jumlah kerikil yang dipegang dan siswa diminta untuk membandingkan jumlah tumpukan kerikil yang satu dengan yang lainnya.

Permainan lain yang digunakan oleh guru pada siklus kedua ini yaitu guru meminta siswa untuk menjawab hasil penjumlahan atau pengurangan yang diberikan, kalau salah maka jumlah kerikil yang ada pada siswa dikurangi dan kalau benar jumlah kerikil ditambah. Setiap penambahan atau pengurangan lidi yang ada pada siswa, ditulis daan hasilnya dihitung. Siswa yang lidinya paling banyak merupakan siswa yang menang dalam permainan dan guru memberikan penghargaan terhadap siswa tersebut. Dengan bentuk-bentuk permainan ini, siswa sekaligus diajak untuk melakukan demonstrasi penjumlahan dan pengurangan yang diharapkan akan mampu meningkatkan kemampuan siswa mengoperasionalkan penjumlahan dan pengurangan. 
Kegiatan penutup tindakan kelas dilakukan dengan guru menyimpulkan hasil pembelajaran yang sudah dilaksanakan. Guru mengadakan tes hasil belajar siswa dengan menggunakan instrumen tes uraian yang terdiri dari 10 item pertanyaan yang sudah disediakan.

Berdasarkan hasil observasi terhadap kegiatan guru dalam melaksanakan kegiatan belajar mengajar, semua hal yang ada dalam instrumen penilaian kegiatan guru dilakukan dengan baik sesuai dengan urutan dalam rancangan pelaksanaan pembelajaran. Hasil pengamatan terhadap kegiatan siswa dalam kegiatan pembelajaran, terlihat bahwa tingkat perhatian siswa, keaktifan siswa dalam bertanya, menjawab pertanyaan dan melakukan demontrasi operasi penjumlahan dan pengurangan sudah meningkat dibanding dengan siklus sebelumnya. Siswa terlihat lebih aktif terlibat dalam pembelajaran dan mampu memahami konsep operasi penjumlahan dan pengurangan dengan baik.

Hasil belajar siswa setelah dilaksanakan tindakan pada siklus II dapat dilihat dalam tabel berikut:

Tabel 3 Distribusi Frekuensi Hasil Belajar Matematika Siswa pada Siklus II

\begin{tabular}{|c|c|c|c|c|}
\hline No & Interval Persentase & Frekuensi & Kriteria & Persentase (\%) \\
\hline 1 & $85-100$ & 2 & Baik Sekali & 6,67 \\
\hline 2 & $75-84$ & 11 & Baik & 36,67 \\
\hline 3 & $60-74$ & 17 & Cukup & 56,66 \\
\hline 4 & $40-59$ & 0 & Kurang & 0,00 \\
\hline \multirow[t]{2}{*}{5} & $0-39$ & 0 & Gagal & 0,00 \\
\hline & Jumlah & 30 & & 100,00 \\
\hline & ata-rata Persentase & $75,00 \%$ & Cukup & \\
\hline
\end{tabular}

Hasil belajar matematika pada siklus II mengalami peningkatan cukup tinggi dibandingkan dengan siklus I. Hal ini bisa dilihat dari banyaknya siswa dengan hasil belajar matematika baik pada siklus II yaitu sebanyak 11 orang atau 36,67\% dari jumlah keseluruhan siswa. Sebanyak 17 siswa $(56,66 \%)$ dengan nilai cukup, dan sebanyak 2 siswa $(6,67 \%)$ dengan nilai baik sekali. Pada siklus II ini tidak ada lagi siswa yang memiliki hasil dalam operasi penjumlahan dan pengurangan kurang ataupun kurang sekali. Rata-rata skor kemampuan siswa dalam materi operasi 
penjumlahan dan pengurangan yaitu sebesar 75,00\%, hal ini berarti hasil belajar matematika siswa pada siklus II berkriteria cukup.

Berdasarkan hasil pengamatan, siklus II mengalami peningkatan yang signifikan dibandingkan dengan siklus-siklus sebelumnya melalui. Pembelajaran siklus kedua secara keseluruhan baik dan tidak dilanjutkan pada siklus berikutnya.

Berikut ini digambarkan perubahan dari siklus pertama sampai siklus kedua sebagai berikut:

Tabel 4 Hasil Pengamatan Kegiatan Siswa pada Saat KBM

\begin{tabular}{clcc}
\hline No. & \multicolumn{1}{c}{ Aspek yang diamati } & Siklus & Siklus \\
& & I & II \\
\hline 1 & Perhatian siswa terhadap penjelasan guru & Sedang & Baik \\
\hline 2 & Perhatian siswa terhadap demonstrasi yang dilakukan oleh guru & Sedang & Baik \\
\hline 3 & Siswa bertanya tentang hal yang belum dimengerti & Kurang & Baik \\
\hline 4 & Keaktifan siswa dalam menjawab pertanyaan. & Sedang & Baik \\
\hline 5 & Keaktifan siswa mengerjakan soal-soal yang diberikan. & Kurang & Baik \\
\hline 6 & Siswa menyelesaikan soal-soal yang diberikan sesuai waktu yang ditentukan & Kurang & Baik \\
\hline 7 & Siswa memahami konsep operasi penjumlahan dan pengurangan & Kurang & Baik \\
\hline 8 & Siswa membantu menjelaskan hal yang belum dimengerti oleh yang lain & Kurang & Baik \\
\hline 9 & $\begin{array}{l}\text { Siswa melakukan peragaan/demonstrasi operasi penjumlahan } \\
\text { pengurangan dengan media benda konkrit }\end{array}$ & Kurang & Baik \\
\hline
\end{tabular}

Berdasarkan tabel di atas dapat dilihat bahwa pada siklus II, terdapat kemajuan dimana siswa menjadi lebih aktif dari siklus sebelumnya. Siswa mampu menjelaskan konsep pengoperasionalan penjumlahan dan pengurangan, siswa juga mampu mendemonstrasikan operasi penjumlahan dan pengurangan dengan baik.

Hasil pengamatan terhadap hasil belajar matematika siswa setiap siklus digambarkan dalam tabel berikut:

Tabel 5 Rangkuman hasil tes hasil belajar siswa

\begin{tabular}{ccccc}
\hline No & Siklus & Rata-rata skor & Rata-rata (\%) & Kriteria \\
\hline 1 & Siklus I & 47,67 & 48,00 & Kurang \\
\hline 3 & Siklus II & 75,00 & 75,00 & Cukup \\
\hline
\end{tabular}

Hasil belajar matematika siswa mengalami peningkatan dari siklus I ke siklus II. Berdasarkan siklus II, didapatkan rata-rata skor kemampuan siswa dalam materi operasi penjumlahan dan pengurangan dengan rata-rata 7,5 dengan persentase nilai 
$75,00 \%$, sedangkan rata-rata skor kemampuan siswa dalam materi operasi penjumlahan dan pengurangan pada siklus I sebesar 47,67 dengan persentase nilai 48,00\%. Hal ini berarti terdapat peningkatan hasil belajar matematika siswa sebesar $27 \%$ dibandingkan dengan siklus I.

Peningkatan hasil belajar siswa dapat dilihat pada grafik berikut ini:

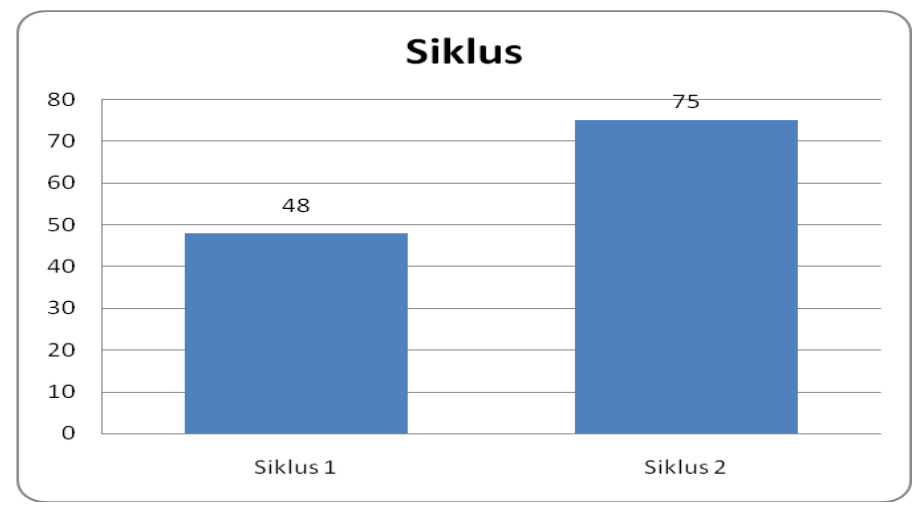

Gambar 1 Grafik hasil belajar matematika siswa

Berdasarkan grafik di atas dapat dilihat bahwa dari setiap siklus, hasil belajar matematika mengalami peningkatan. Hasil belajar matematika pada siklus II, mengalami peningkatan yang signifikan dibandingkan dengan hasil belajar matematika pada siklus I. Pada siklus II, rata-rata persentase nilai hasil belajar matematika yaitu 74,76\%, sedangkan pada siklus I hanya 49,52\%.

\section{KESIMPULAN DAN SARAN}

Dari hasil penelitian yang telah dilakukan, dapat disimpulan bahwa pada siklus I rata-rata hasil kemampuan siswa dalam mengoperasionalkan penjumlahan dan pengurangan menggunakan metode demonstrasi tergolong masih kurang dengan nilai rata-rata hasil tes 47,67 dan persentase nilai sebesar $48 \%$. Pada siklus II, ratarata hasil kemampuan siswa dalam mengoperasionalkan penjumlahan dan pengurangan menggunakan metode demonstrasi berkategori cukup dengan peningkatan hasil nilai rata-rata tes sebesar 7,5 dan persentase nilai sebesar $75 \%$. 
Berdasarkan hasil penelitian, maka pembelajaran operasi penjumlahan dan pengurangan menggunakan metode demonstrasi dapat meningkatkan kemampuan siswa kelas SDN No. 101/II Muara Bungo Kecamatan Pasar Muara Bungo Kabupaten Bungo. Saran bagi guru yakni dalam mengajar matematika menggunakan metode yang bervariasi dan media pembelajaran inovatif untuk meningkatkan kemampuan dan hasil belajar siswa.

\section{DAFTAR PUSTAKA}

Arikunto,Suharsimi, dkk.2010.Penelitian Tindakan Kelas. Jakarta:Bumi Aksara Depdiknas.2006. Kurikulum 2006 Standar Kompetensi Mata Pelajaran. Jakarta: Depdiknas.

Muhsetyo, G. 2005. Pembelajaran Matematika SD. Jakarta: Universitas Terbuka. Ruseffendi 1991. Pendekatan Model Pembelajaran Ekspositori. Jakarta: Gema Ilmu Suherman, Erman dkk. 2006. Strategi Pembelajaran Matematika Konteporer. Bandung: Jica Jurusan Pendidikan Matematika FMIPA Universitas Pendidikan Indonesia

Wardhani, S. 2004. Penilaian Pembelajaran Matematika Berbasis Kompetensi. Yogyakarta: Widyaiswara PPPG Matematika Departemen Pendidikan Nasional. 